\title{
Concentration and accumulation of some trace elements in water, sediment and two species of aquatic plants collected from the Main outfall drain, near the center of Al-Nassiriyia city/ Iraq \\ تركيز وتراكم بعض العناصر النزرة في الماء والرواسب ونوعين من النباتات المائية المستجمعه من المصب

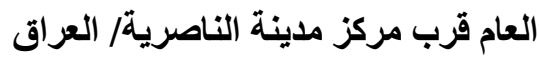

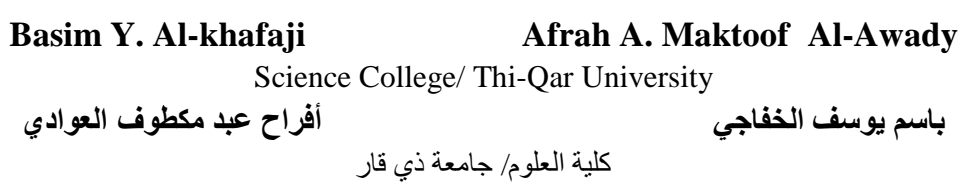

\begin{abstract}
:
Concentration and accumulation of seven trace elements $(\mathrm{Cd}, \mathrm{Cu}, \mathrm{Pb}, \mathrm{Ni}, \mathrm{Fe}, \mathrm{Mn}$ and $\mathrm{Zn}$ ) were measured in water (dissolved and particulate) phase, sediment and two species of aquatic plants phragmits australis and Ceratophylum demerssum collected during summer season, 2012 from the main outfall drain, some environmental parameter (Temperature, dissolved oxygen, salinity, $\mathrm{pH}$ ) of water were measured, also total organic carbon TOC\%, sediment texture were measured and expressed as percentage. Higher concentration of elements under study were observed in sediment more than their concentrations in water and plants, while particulate phase of water concentrated trace elements more than their concentration in dissolved phase, whereas the accumulation of trace elements in plants, showed that their concentration in phragmits australis was more than their concentration in Ceratophyllum demerssum. The study observed that it can use the two species of plants as bioindicator for accumulation of trace elements also the concentration of $\mathrm{TE}$ in the study samples were in acceptable range, when it compared with world wide range. The study showed that the possibility of using both plants to remove this type of pollutant from the aquatic environment and can be used in bioremediation for processes.
\end{abstract}

Key words: trace elements, aquatic plants, sediment

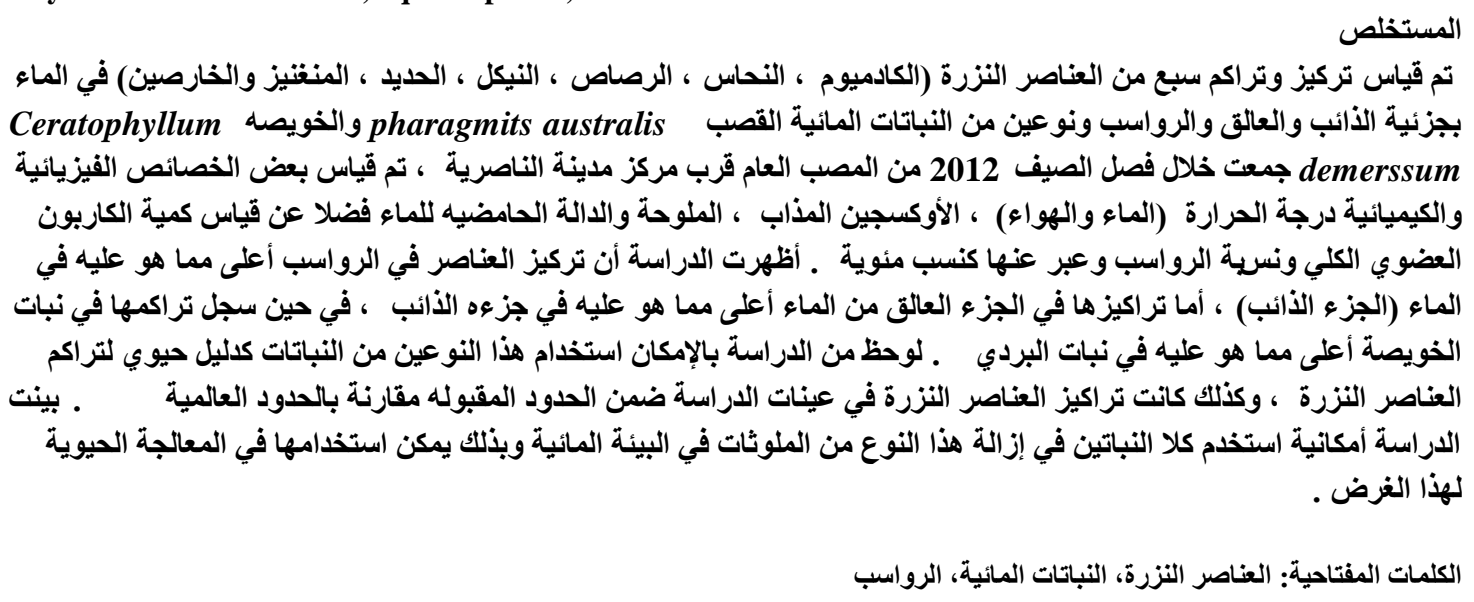

Introduction:

The pollution of water course with non biodegradation pollutants such as trace elements, chlorinated hydrocarbons and oil, is a serious problem [1]. Environmental pollution is a problem with high urgency in modern society out of the various kinds of pollution, the high contamination of aquatic system with toxic trace elements is one of a major concern since, these elements aren't biodegradable and their elevated uptake by crops may also affected food quality system mainly through nature input such as weathering and erosion of rocks and anthropogenic sources including urban, industrial and agricultural activities, terrestrial runoff and sewage disposal [2]. Trace elements discharge into aquatic system may be immobilized within the stream sediment by main processes such as adsorption and co-precipitation therefore, sediments in aquatic environmental serve as a pool that can retain metals or release metals to the water column by various processes of remobilization [3]. High levels of $\mathrm{Cd}, \mathrm{Co}, \mathrm{Cu}, \mathrm{Cr}, \mathrm{Fe}, \mathrm{Mn}, \mathrm{Ni}$, $\mathrm{Pb}$ and $\mathrm{Zn}$ were reported [4] in fish and submerging plants of the Ganges river and in water, sediment, 
plant and fish of the Yamma river, India. studied trace elements in aquatic plant tissues [5], they found that Potamogeton pedtinatus accumulated trace elements more than those of G. densa therefore, all plants can be used as biological indicators while determing environmental stress, however phragmits australis has provide more appropriate [6] as well as [7] study the concentrations of trace elements in aquatic plants and sediment of the southern marsh. Despite the different matrices, sediments have been more analyzed because they present a clear indication of metal inputs and accumulation in aquatic environments [8]. Although the plants are considered an essential part of the food web in the region [9]. The development of the industry and expansion of the using of chemical compounds in different branches of industry leading to the environmental spread of trace elements and the increasing pollution with many trace elements in the southern river of Iraq has been the subject of considerable interest [10, 11, 12].

The aim of this study is to investigate trace elements ( $\mathrm{Cd}, \mathrm{Cu}, \mathrm{Ni}, \mathrm{Pb}, \mathrm{Mn}, \mathrm{Fe}$ and $\mathrm{Zn}$ ) concentration and distribution in water, sediment and plants from main outfall Drain River and to assess the contamination status using various elements assessment indices, also to know the potential of using the plants under the study in phytoremedation in future.

In this work the concentrations of $\mathrm{Cd}, \mathrm{Cu}, \mathrm{Ni}, \mathrm{Pb}, \mathrm{Mn}, \mathrm{Fe}$ and $\mathrm{Zn}$ were determinate in water, sediment and two of plants species Ceratophyllum demerssum and Phrgamtus australis collected from main outfall Drain River.

\section{Materials and methods}

\section{The Study area description}

Main outfall drain is a river use to discharge the effluents of agriculture activities from its both sides. It is extended from Al-Shaklawiya near Baghdad from the north until Al-until Basrah at the south with length about $565 \mathrm{~km}$ [13]. It is dividing into three sectors (North, Middle and South), the south sector (which the present study area is a part of it) extended from the end of the mid sector until Shatt AlBasarah in the south, with length about $165 \mathrm{~km}$. The discharge of water is about $220 \mathrm{~m}^{3} / \mathrm{sec}$ in it sector was use to sector [14]. New branch was opened in this sector with length $7 \mathrm{~km}$, transform the water to southern marshes of Al-Nassiriya city.

Three stations were selected in the south sector of this river to implemented, the present study, these are station 1(St.1) was near Al-Holandee bridge and the general carriage in the center of Al-Nassiriya city, St. 2 was $20 \mathrm{~km}$ far from the first station, while St. 3 was in the beginning of the new branch as shown in Fig.(1).

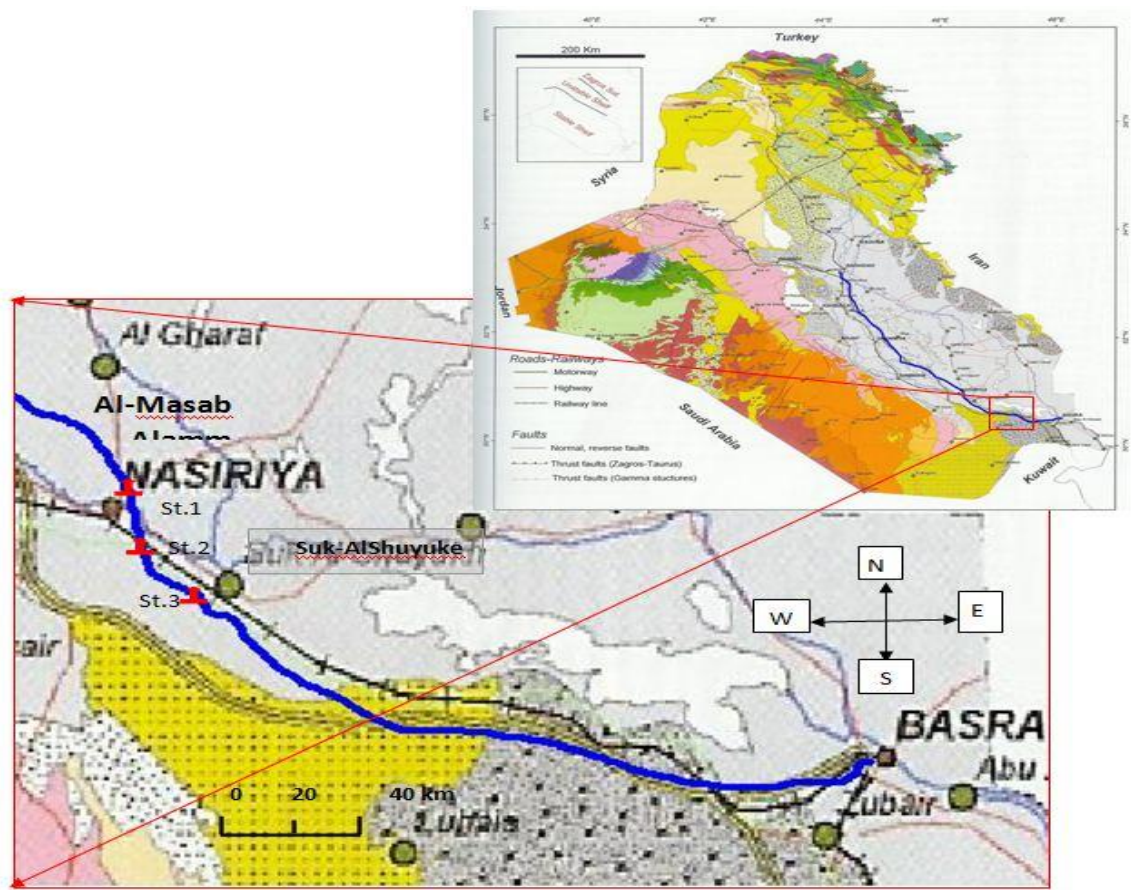

Fig(1): Map of the study area showed the study stations. 


\section{Samples collection}

Samples of water, sediment and plants were collected from MOD river during summer (May, June, July, August and September) 2012. 5 liters of water were taken from each station were collected by using polyethylene bottles with capacity $5 \mathrm{~L}$. The sediment samples were collected by using van veen grab sampler, and plants were collected from the same area, then placed in plastic bags and all samples (water, sediment and plants) preserved in a cooling box until reaching the laboratory. Also air and water temperature $\left({ }^{\circ} \mathrm{C}\right), \mathrm{pH}$, dissolved oxygen (Do) $\mathrm{mg} / \mathrm{L}$ and water electrical conductivity $(\mathrm{EC} \mu \mathrm{s} / \mathrm{cm}$ ) were measured in the field by using Cyberscan 600 water proof portable meter, made in Singapore. The salinity was calculated according to the following equation.

Salinity $\%_{0}=\mathrm{EC}\left(\mu \mathrm{s} / \mathrm{cm}^{*} 0.64 / 1000\right.$.

\section{Procedure}

\section{Salinity values expressed as part per thousands (ppt).}

\section{Trace elements measurement}

Water samples were digested according to the method described by [15], while sediment was digested after drying according to [16] method. The samples of plant were freeze dried and ground with agate mortar (1g dry weight) then digested according to the procedure described by [17]. Triplicates with blanks solution were used for each sample (water, sediment and plants) in the present study. The levels of $(\mathrm{Cd}, \mathrm{Cu}, \mathrm{Ni}, \mathrm{Pb}, \mathrm{Mn}, \mathrm{Fe}$ and $\mathrm{Zn})$ in extractions were determined by air-acetylene flame atomic absorption spectrophotometers Shimadzu- 630-12 using different cathode lamps with air acetylene flam method, while elements concentration value were calculated from the calibration curve according to a specific method [18].

Total organic carbon TOC\% content in the sediment was estimated by using a procedure described by [19], while sediment particles size analysis was analyzed mechanically by using a hydrometer and the percentage of different sediment particles (sand, silt and clay) were calculated according to the method of $[20,21]$.

\section{Results and Discussion}

Table(1) shows the values of physical and chemical factors in the study area. The values of air temperature ranged from $31.32^{\circ} \mathrm{c}$ at st. 1 in September to $39.6^{\circ} \mathrm{c}$ at st. 3 in August, whilst water temperature values ranged from $21.86^{\circ} \mathrm{c}$ at st. 1 in September to $32.00^{\circ} \mathrm{c}$ at st. 3 in August. Temperature is an important factor, which regulates the biogeochemical activities in the aquatic environment [22].

The present study data showed that water temperature was affected by changes in air temperature that was due to the shallowness and small surface area in comparison with volume [23].

There are differences in the temperature among the station over the day and that come from the different time of sampling taking. These are agree with the [24, 25, 12]. The water salinity values for all stations varied between (4.01- 8.96) \%.

The highest levels of salinity (8.95) \%o were recorded in August at station 1, while the lowest level (4.01) \% was recorded in June at station 3. The higher values of salinity was observed in the study for the MOD because this river used as drainage water supply and this due to the levels of salinity were increased during the summer months, that was caused by increasing of the evaporation rate and low water level [26].

Hydrogen ion concentration $(\mathrm{pH})$ showed slight fluctuations in water during the study period the $\mathrm{pH}$ was alkaline level, it has being know that Iraq water mainly tend to be alkaline, this agree with obtained by $[27,28]$. The daily differences in $\mathrm{pH}$ values were because of removing carbon dioxide from bicarbonate by photosynthesis process during hours [29] or in water with high plant concentration. $\mathrm{pH}$ played an important role in solubility and hence trace elements mobilize in the water column. The low $\mathrm{pH}$ value lead to an increased concentration of metals in the dissolved phase [30]. Dissolved oxygen play an important role in aquatic environment. Some physical and biological factors affected the bioavailability of DO in water. These include temperature, salinity and amount of organic matter [31]. Oxidative consumption was confirmed by the result of this study when the lowest value of Do at st.1, the water here was affected by the input of easily biodegradable human and animal waste. Rising temperature lead to an increased metabolic activity for microorganisms and this lead to increase Do 
consumption through the respiration [25], The values of Do in this study were consistent with the [1, 25, 32] studies.

Table(1): Mean values of some environment factors in the study area during the study period.

\begin{tabular}{|c|c|c|c|c|c|c|}
\hline Months & Stations & Air Temp. ${ }^{\circ} \mathbf{c}$ & Water emp. ${ }^{\circ} \mathbf{c}$ & Salinity \%o & pH & Do (mg/l) \\
\hline \multirow{3}{*}{ May } & $\mathbf{1}$ & 34.55 & 26.30 & 6.00 & 8.45 & 7.50 \\
\hline & 2 & 35.24 & 27.20 & 4.99 & 7.65 & 7.65 \\
\hline & 3 & 36.42 & 27.70 & 4.25 & 7.44 & 7.85 \\
\hline \multirow{3}{*}{ June } & 1 & 34.96 & 26.76 & 7.01 & 8.35 & 6.9 \\
\hline & 2 & 35.60 & 27.55 & 5.00 & 7.55 & 6.85 \\
\hline & $\overline{3}$ & 37.10 & 28.35 & 4.01 & 7.35 & 6.90 \\
\hline \multirow{3}{*}{ July } & 1 & 37.22 & 30.60 & 7.10 & 8.50 & 6.4 \\
\hline & 2 & 38.30 & 31.22 & 5.13 & 7.84 & 6.6 \\
\hline & 3 & 39.05 & 31.10 & 4.30 & 7.65 & 6.8 \\
\hline \multirow{3}{*}{ August } & 1 & 37.50 & 30.80 & 8.96 & 8.65 & 6.07 \\
\hline & 2 & 38.23 & 31.86 & 8.03 & 7.92 & 6.20 \\
\hline & 3 & 39.6 & 32.00 & 7.96 & 7.80 & 6.15 \\
\hline \multirow{3}{*}{ September } & 1 & 31.32 & 21.86 & 6.2 & 8.45 & 7.79 \\
\hline & 2 & 32.00 & 22.88 & 5.30 & 7.85 & 7.82 \\
\hline & 3 & 33.08 & 23.00 & 5.05 & 7.65 & 7.89 \\
\hline
\end{tabular}

Trace elements in water

The result of analysis for $\mathrm{Cd}, \mathrm{Cu}, \mathrm{Ni}, \mathrm{Pb}, \mathrm{Mn}, \mathrm{Fe}$ and $\mathrm{Zn}$ in water ( dissolved and particulate) clarify in Table(2).

Table(2): Concentrations (Mean \pm SD) of trace elements in water (dissolved $\mu \mathrm{g} / \mathrm{l}$ and particulate $\mu \mathrm{g} / \mathrm{g}$ dry weight) phases in the study station.

\begin{tabular}{|c|c|c|c|c|c|c|c|c|}
\hline \multirow{2}{*}{ 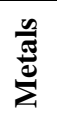 } & \multicolumn{2}{|c|}{ Station 1} & \multicolumn{2}{|c|}{ Station 2} & \multicolumn{2}{|c|}{ Station 3} & \multicolumn{2}{|c|}{$\begin{array}{l}\text { Mean concentration in } \\
\text { the region }\end{array}$} \\
\hline & Diss. \pm SD & Parti \pm SD & Diss. \pm SD & Parti \pm SD & Diss. \pm SD & Parti \pm SD & Diss. \pm SD & Parti \pm SD \\
\hline Cd & $0.09 \pm 0.03$ & $16.14 \pm 1.98$ & $0.06 \pm 0.01$ & $13.58 \pm 1.20$ & $0.03 \pm 0.001$ & $10.87 \pm 1.16$ & $0.06 \pm 0.011$ & $13.53 \pm 1.44$ \\
\hline $\mathrm{Cu}$ & $0.14 \pm 0.016$ & $27.06 \pm 2.93$ & $0.11 \pm 0.009$ & $24.01 \pm 3.95$ & $0.08 \pm 0.009$ & $20.03 \pm 2.76$ & $0.11 \pm 0.01$ & $23.7 \pm 2.54$ \\
\hline $\mathbf{N i}$ & $3.12 \pm 0.86$ & $68.85 \pm 0.66$ & $1.99 \pm 0.16$ & $64.82 \pm 0.50$ & $0.95 \pm 0.08$ & $45.06 \pm 0.44$ & $2.02 \pm 0.64$ & $59.57 \pm 0.53$ \\
\hline $\mathbf{P b}$ & $0.70 \pm 0.08$ & $43.63 \pm 8.13$ & $0.60 \pm 0.20$ & $39.29 \pm 5.91$ & $0.48 \pm 0.15$ & $35.28 \pm 3.31$ & $0.59 \pm 0.14$ & $39.4 \pm 3.11$ \\
\hline Mn & $3.59 \pm 0.40$ & $\begin{array}{c}270.63 \pm \\
35.66\end{array}$ & $3.00 \pm 0.20$ & $\begin{array}{c}200.79 \pm \\
20.40\end{array}$ & $1.95 \pm 0.12$ & $\begin{array}{c}180.79 \pm \\
19.20\end{array}$ & $2.84 \pm 0.24$ & $\begin{array}{l}217.40 \pm \\
25.08\end{array}$ \\
\hline $\mathbf{F e}$ & $\begin{array}{c}190.62 \pm \\
19.17\end{array}$ & $\begin{array}{c}3193 . .21 \pm \\
578.621\end{array}$ & $\begin{array}{l}160.19 \pm \\
30.25\end{array}$ & $\begin{array}{c}2399.71 \pm \\
896.59\end{array}$ & $\begin{array}{c}120.37 \pm \\
25.36\end{array}$ & $\begin{array}{c}1999.69 \pm \\
887.68\end{array}$ & $\begin{array}{c}157.06 \pm \\
24.92\end{array}$ & $\begin{array}{c}2030.87 \pm \\
787.62\end{array}$ \\
\hline $\mathbf{Z n}$ & $21.16 \pm 2.92$ & $98.01 \pm 4.03$ & $18.13 \pm 4.00$ & $89.35 \pm 10.0$ & $14.10 \pm 2.50$ & $63.06 \pm 8.01$ & $17.79 \pm 2.14$ & $\begin{array}{c}83.47 \pm \\
11.68\end{array}$ \\
\hline
\end{tabular}

The partition of metals between dissolved and suspended particulate matter determines their ultimate fate in the aquatic environments. The mean concentrations $\mu \mathrm{g} / \mathrm{L}$ of the mentioned metals in dissolved phase at the study station $(1,2$ and 3$)$ were follows; $\mathrm{Cd}(0.09,0.06,0.03) ; \mathrm{Cu}(0.14,0.11,0.08)$; Ni $(3.12,1.99,0.95) ; \mathrm{Pb}(0.70,0.60,0.48) ; \mathrm{Mn}(3.59,3.00,1.95) ; \mathrm{Fe}(190.62,160.19,120.37)$ and $\mathrm{Zn}$ $(21.16,18.13,14.10)$ respectively. Metals concentration at St.1 were higher than their concentration in station 2, 3, this may be due to the close of the mentioned station from the region with high population density also it is situated close from the general garage of Al-Nassiriya city. So as a result of numerous processes happen in the garage for cars washing, therefore, the product of the mention process, directly discharge without any treatment to the cannel of MOD near the mentioned station 1.

Trace elements in particulate matter were higher than their concentrations in dissolved phase for three stations Table(2). This may be due to the high amount of particulate matter in the study area during the study period. Decrease metals concentration in dissolved for river water may be due to adsorb TMs on sediment surfaces or complexes compound with organic matter [33, 34, 32] or accumulation TMs in plankton, aquatic plants and aquatic organism [35, 36]. Plankton organisms tend to concentrate TMs as high as $10^{6}$ times their level in water [37], also the concentration of the trace elements in aquatic environment depends on many factors such as water discharge of the river, seasonal variations in quantities and qualitative of plankton and suspended material load of the river [38]. 
The concentration of dissolved trace elements is similar to those reported elsewhere, also its concentrations in the present study are in an acceptable range compared with the world wide Table $(2,3)$ respectively.

Table (3): Comparison mean values of dissolved trace elements $(\mu \mathrm{g} / \mathrm{L})$ in the present study with the other studies elsewhere.

\begin{tabular}{|c|c|c|c|c|c|c|c|c|}
\hline Location & Cd & $\mathbf{C u}$ & $\mathbf{N i}$ & $\mathbf{P b}$ & Mn & $\mathrm{Fe}$ & $\mathbf{Z n}$ & References \\
\hline $\begin{array}{l}\text { Al-Hillia river- } \\
\text { Iraq }\end{array}$ & 1.09 & 1.81 & 0.27 & 4.21 & 0.96 & 6.74 & 8.73 & 39 \\
\hline $\begin{array}{c}\text { Shatt Al-Arab } \\
\text { river Basrah- } \\
\text { Iraq }\end{array}$ & 25.00 & - & 1209.00 & 95.00 & - & - & 1364.00 & 40 \\
\hline $\begin{array}{c}\text { Euphrates river } \\
\text { (between Al- } \\
\text { Hindia dam, } \\
\text { Kufa region) }\end{array}$ & 2.14 & 2.48 & 0.07 & 0.10 & 6.12 & 105.69 & 10.50 & 41 \\
\hline $\begin{array}{l}\text { Al-Hammar } \\
\text { marsh south of } \\
\text { Iraq }\end{array}$ & - & 0.7 & 2.13 & 0.16 & - & - & - & 42 \\
\hline $\begin{array}{c}\text { MOD river } \\
\text { Iraq near Al- } \\
\text { Nassiriyia city }\end{array}$ & 0.05 & 0.03 & 1.73 & 0.35 & 2.42 & 154.05 & 12.12 & 25 \\
\hline World wid & 0.22 & 7.0 & - & 3.0 & - & - & 20 & 43 \\
\hline $\begin{array}{c}\text { MOD river Iraq } \\
\text { near Al-Nassiriyia } \\
\text { city }\end{array}$ & 0.06 & 0.11 & 2.02 & 0.59 & 2.84 & 157.06 & 17.79 & $\begin{array}{l}\text { Present } \\
\text { study }\end{array}$ \\
\hline
\end{tabular}

Trace elements in sediment

A major part of the heavy metals, that enter the aquatic environment eventually settle in the sediment [44]. So the sediment act as archives for many pollutants one of these are heavy metals [42]. Concentration of heavy metals in sediment showed in table (4). In the present study there were higher concentration of heavy metals observed at st. 1 compared to st. 2 and st. 3 this was due to the location of st.1 near to residential areas, which discharged their waste directly into the MOD without treatment. These wastes increased the organic matter in the sediment Toc\% content in the st.1 was more than its content in st.2 and st.3 during summer Figure (2). The mean concentrations of trace elements were $\mathrm{Cd}(4.87), \mathrm{Cu}(16.5), \mathrm{Ni}(45.86), \mathrm{Pb}(23.4), \mathrm{Mn}(259.69), \mathrm{Fe}(2237.58)$ and $\mathrm{Zn}(22.65) \mu \mathrm{g} / \mathrm{g}$ dry wt. concentration of TMs under study in sediment were higher than their concentrations in dissolved phase of water and lower than their concentrations in particulate phase of water. This mean that particulate phase play an important role to support sediment by heavy metals. In addition, the increasing of the plants density in the study area played an important role in increasing the concentration of trace elements in the sediment. Plants work to reduce the velocity of water flow and this led to the deposition of suspended matter containing trace elements in the sediments. Sediment particles size also plays an important role in the distribution and concentration of heavy metals. Description of the sediment texture at st.1. Small particle size, such as silt and clay tend to accumulate higher concentration of heavy metals because of the availability of large surface area that allowed adsorption of metals into the surface of particles [45,42]. This was confirmed by the high concentration of heavy metals in the sediment at st.1 comparing with st. 2 and st.3, because st. 1 contained a high content of silt $26 \%$ and clay $50 \%$ compared with st.2 which contained a high amount of sand 55\% Figure(3), as well there was an increased concentration of trace elements in sediment in summer month Table (4) this is due to the high temperature which have a role in killing some phytoplankton and zooplankton and thereby increasing the deposit and accumulation of these materials, which increase the metal concentration in the sediment [46]. In addition high temperature lead to increase salinity through evaporation, when salinity increases the bond between the metals and suspended matter becomes stronger. This strong bond makes suspended material insoluble in water and then increases the deposition of these substances in the sediment. 
Table (4): Mean concentrations ( $\mu \mathrm{g} / \mathrm{g}$ dry weight) of trace elements in sediment for all study stations during study period.

\begin{tabular}{|c|c|c|c|c|c|}
\hline \multirow{2}{*}{$\begin{array}{c}\text { Trace } \\
\text { elements }\end{array}$} & \multicolumn{3}{|c|}{ Stations } & \multirow{2}{*}{$\begin{array}{c}\text { Mean } \\
\mu g / g m \\
\text { dry wt. }\end{array}$} & \multirow{2}{*}{$\begin{array}{l}\text { Standard } \\
\text { deviation }\end{array}$} \\
\hline & Station 1 & Station 2 & Station 3 & & \\
\hline Cd & $7.16 \pm 0.10$ & $5.09 \pm 0.07$ & $2.38 \pm 0.04$ & 4.87 & 0.07 \\
\hline $\mathbf{C u}$ & $24.39 \pm 1.89$ & $16.40 \pm 1.64$ & $9.47 \pm 2.23$ & 16.5 & 1.92 \\
\hline $\mathbf{N i}$ & $\mathbf{5 0 . 0 1} \pm \mathbf{2 0 . 7 0}$ & $45.69 \pm 11.86$ & $40.10 \pm 4.05$ & 45.86 & 12.20 \\
\hline $\mathbf{P b}$ & $33.25 \pm 11.65$ & $27.69 \pm 3.35$ & $9.26 \pm 2.04$ & 23.4 & 5.68 \\
\hline Mn & $296 \pm 105.01$ & $250 \pm 96.03$ & $203.08 \pm 50.60$ & 459.69 & 83.88 \\
\hline $\mathbf{F e}$ & $2623.96 \pm 391.61$ & $2280.5 \pm 280.97$ & $1808.3 \pm 199.80$ & 2237.58 & 290.79 \\
\hline Zn & $30.17 \pm 1.32$ & $20.89 \pm 4.36$ & $16.90 \pm 2.08$ & 22.65 & 2.58 \\
\hline
\end{tabular}

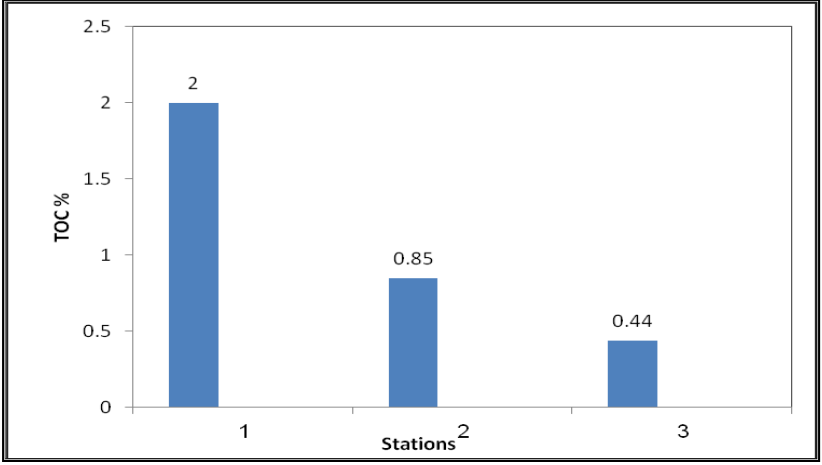

Fig (2): Total organic carbon Toc\% content in the study stations during the study period

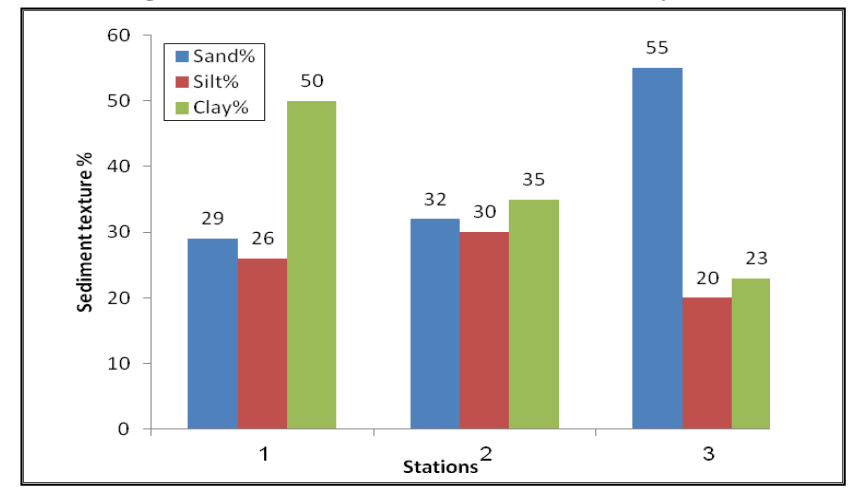

Fig (3): Sediment texture\% for the station.

\section{Trace elements in plants}

Aquatic plants have been shown to accumulate trace elements in their tissues and therefore have been used as biological indicators for metal pollution monitoring in the aquatic ecosystem. Table (5) shows the distribution of trace elements in aquatic plants of MOD river. The ability of plants to accumulation and elimination trace elements in relation to their concentration in ambient led to the observed variation in metal concentration in plants. The results showed higher concentration of trace elements in sediment than their concentration in plants these result were agreed with [7, 47, 48].

In this study there were differences in the trace elements concentrations between stations and a less clear difference between the selected plants. There were higher levels of trace elements in both species of plants $P$. austeralis and $C$. demerssum in station 1 than in station 2 and station 3 . This was due to two reasons. Firstly, station 1 had exposure to different types of pollutants such as sewage, oil spilt from boats and chemicals used for fishing, while station 2 and 3 was less polluted. Secondly, the level of organic carbon in the sediment at station 1 was higher than its level at station2 and 3figure (2) as a result of sewage pollution. The metals remained in the sediments at station 1 for long periods of time and this provided greater opportunity for the plants to absorb, the range of cadmium concentration was $0.82-2.01 \mu \mathrm{g} / \mathrm{g}$ dry weight followed by lead $0.83-2.23 \mu \mathrm{g} / \mathrm{g}$ dry weight, while Iron have shown the 
highest levels in the two species. The other elements are generally arranged in the following order of abundance $\mathrm{Zn}>\mathrm{Ni}>\mathrm{Mn}>\mathrm{Cu}$.

Generally, this study showed that the highest mean for trace elements concentration was in the particulate phase, followed by the sediments, then the plants and was lowest in the dissolved phase. The reason for the high concentrations in the particulate phase is due to continuous movement of water and the lack of time for deposition of the suspended solids [27,48]. The reason for the higher concentrations in sediment compared with plants and in dissolved phase is due to the plants density in the study area, which reduced water speed and thus provided an opportunity for the deposition of the maximum amount of suspended matter.

The higher concentration of elements in plants than in the dissolved phase is due to the concentration in sediments, which work to keep the trace elements as long as possible and thus provide the opportunity for plants to absorb these metals [7]. The cause of the low concentration in the dissolved phase compared to other phases is due to the effect of various physical and chemical factors such as salinity, temperature and $\mathrm{pH}$, which leads to adhesion of metals with suspended materials, thereby reducing the concentrations of metals in the dissolved phase.

Finally, the results also showed the highest of metals in all stages (water, sediment and plants) were Fe, $\mathrm{Ni}$ and $\mathrm{Zn}$. This is probably due to the source of pollution (sewage, oil splits from boats the use of toxic chemicals in the process of fishing) which have high levels of these metals. There may be some contribution from the geology of the region, which may contain naturally higher concentrations of these metals [28].

Table (5): Concentrations (Mean \pm SD) of trace elements in two plants (C.demerssum and $P$. austeralis) $\mu \mathrm{g} / \mathrm{g}$ in the study station.

\begin{tabular}{|c|c|c|c|c|c|c|c|c|}
\hline \multirow[b]{2}{*}{$\frac{\frac{n}{\pi}}{\sum^{\frac{\pi}{2}}}$} & \multicolumn{2}{|c|}{ Station 1} & \multicolumn{2}{|c|}{ Station 2} & \multicolumn{2}{|c|}{ Station 3} & \multicolumn{2}{|c|}{$\begin{array}{c}\text { Mean concentration in } \\
\text { the region }\end{array}$} \\
\hline & 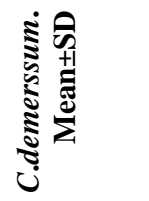 & 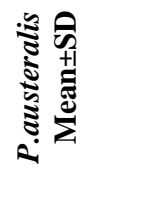 & 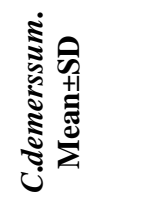 & 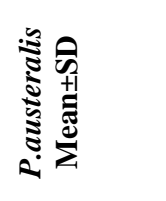 & 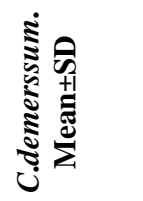 & 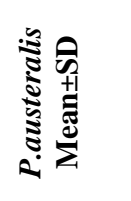 & 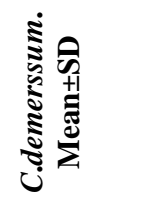 & 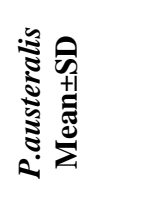 \\
\hline $\mathrm{Cd}$ & $2.01 \pm 0.82$ & $1.78 \pm 0.76$ & $1.55 \pm 0.56$ & $1.30 \pm 0.35$ & $0.86 \pm 0.12$ & $\begin{array}{c}0.82 \pm 0.0 \\
6\end{array}$ & $1.47 \pm 0.5$ & $1.3 \pm 0.39$ \\
\hline $\mathbf{C u}$ & $2.78 \pm 0.99$ & $2.60 \pm 0.96$ & $2.00 \pm 1.00$ & $1.86 \pm 0.85$ & $0.99 \pm 0.13$ & $\begin{array}{c}0.90 \pm 0.1 \\
1\end{array}$ & $1.92 \pm 0.70$ & $1.78 \pm 0.64$ \\
\hline $\mathbf{N i}$ & $\begin{array}{c}18.19 \pm 3.1 \\
2\end{array}$ & $16.03 \pm 3.03$ & $12.20 \pm 3.23$ & $10.17 \pm 3.21$ & $9.16 \pm 1.06$ & $\begin{array}{c}8.13 \pm 1.9 \\
6\end{array}$ & $13.18 \pm 2.47$ & $11.44 \pm 2.73$ \\
\hline $\mathbf{P b}$ & $2.23 \pm 0.85$ & $1.9 \pm 0.82$ & $1.80 \pm 0.65$ & $1.79 \pm 0.67$ & $0.87 \pm 0.09$ & $\begin{array}{c}0.83 \pm 0.0 \\
9\end{array}$ & $1.63 \pm 0.53$ & $1.50 \pm 0.52$ \\
\hline Mn & $6.94 \pm 2.01$ & $5.69 \pm 2.01$ & $17.16 \pm 3.64$ & $3.01 \pm 1.12$ & $2.33 \pm 0.99$ & $\begin{array}{c}2.02 \pm 0.9 \\
9\end{array}$ & $8.81 \pm 2.21$ & $3.57 \pm 1.37$ \\
\hline $\mathbf{F e}$ & $\begin{array}{c}180.57 \pm 2 \\
8.01\end{array}$ & $\begin{array}{c}170.13 \pm 16 \\
31\end{array}$ & $\begin{array}{l}113.03 \pm 18 \\
01\end{array}$ & $\begin{array}{c}107.20 \pm 18 . \\
01\end{array}$ & $\begin{array}{c}86.31 \pm 10 . \\
10\end{array}$ & $\begin{array}{c}80.91 \pm 4 . \\
31\end{array}$ & $\begin{array}{c}126.63 \pm 18 \\
70\end{array}$ & $\begin{array}{c}119.41 \pm 12 . \\
87\end{array}$ \\
\hline $\mathbf{Z n}$ & $\begin{array}{c}28.77 \pm 6.0 \\
1\end{array}$ & $24.86 \pm 4.21$ & $3.13 \pm 1.28$ & $13.08 \pm 3.21$ & $\begin{array}{c}12.10 \pm 2.0 \\
6\end{array}$ & $\begin{array}{c}11.13 \pm 1 \\
16\end{array}$ & $14.72 \pm 3.11$ & $16.35 \pm 2.86$ \\
\hline
\end{tabular}

Conclusions

1. The variability in the levels of trace elements concentration in two species could be ascribed to biological variation between them rather than environmental factors.

2. The highest mean concentrations of trace elements were in the particulate phase, followed by the sediment, than the plants and was lowest in the dissolved phase. The trend of elements concentration was sediment $>$ plants $>$ water(dissolved phase)

3. Iron, Zinc and Nickel recorded higher concentration in all studied samples.

4. TEs in P. austeralis and C. demerssum come from the same source.

5. C. demerssum accumulated trace elements more than P. austeralis.

6. At the station 1 and station 2 .The clay fraction was greater than sand fraction, this due to the associated of trace elements with fine particles size in clay.

7. Low concentrations of studied elements in the study area were not polluted by this type of pollutant according to WHO. 


\section{References:}

1. Al-Khafaji, B.Y. (1996). Trace metal in water, sediments and fishes from Shatt Al-Arab estuary north-west Arabian Gulf. Ph.D. Thesis, Univ. of Basrah. 131 pp.

2. Çevik, F., Göksu, M.Z.L., Derici, O.B. and Findik, Ö. (2009). An assessment of metal pollution in surface sediments of Seyhan dam by using enrichment factor, geoaccumulation index and statistical analyses. Environ. Monit. Assess. 152: 309-317.

3. Marchand, C., Lalliet Verges, E., Baltzer, F., Alberic, P., Cossa, D. and Baillif, P. (2006). Heavy metals distribution in mangrove sediments along the mobile coastline of French Guiana. Mar. Chem. 98:1-17.

4. Ajmel, M., Raziuddin, M. and Ahsan, U. (1983). Heavy metals in water, sediment, fish and plants of river Hindon, U.P. India, Hudrobiologica. 148:151-157.

5. Dileek, D. and Ahmet, A. (2006). Common hydrophytes as bioindicators of iron and manganese pollution. Ecological indicators.6:388-393.

6. Al-Haidary, M.J. (2003). Some ecological effects of industrial wastewater released from the AlFurat company for chemical industries near saddate Al-Hindiyial IRAQ, MSc thesis, Biology Department, College of science, Babylon university.110pp.

7. Awad, N.A., Abdulsahib, H.T. and Jaleel, A.A. (2008). Concentrations of trace metals in aquatic plants and sediments of the southern marshes of Iraq (Al-Hawizah and Al-Hammar) marsh Bulletin3. (1):57-66.

8. Thomas, R.L. (1972). The distribution of mercury in the sediments of Lake Ontario. Can.j. Earth Sci. 9:636-651.

9. Al-Awady, A.A.M. (2013). Feeding habits of (Cyprinus carpio, L.1758) in Main outfall drain near the center of Al-Nassiriya city, south Iraq. (Accepted publication in the journal of the science of ThiQar).

10. Mustafa, Y.Z., Al-Saad, H.T. and Al-Timari, A.A. (1995). Seasonal variations of trace elements in aquatic vascular plants from Al-Hammar marsh, Iraq. Marina Mesopotamica. 10(2): 321-329.

11. Bedair, H.M., Al-Saad, H.T. and Salman, N.A. (2006). Southern marshes something to be conserved: A case study. Marsh Bulletin. 2(1): 99-126.

12. Lazim, I.I. (2013). Concentration of some trace elements in water, sediment and females of two species of fish in the Euphrates river near the center of Al-Nassiriya city, south of Iraq. M.Sc. Thesis, Univ. of Thi-Qar. $110 \mathrm{pp}$.

13. Al-Kubaysi, A.Al.R. (1996). The ecological study of suddam river. Ph.D. Thesis. Univ. of aghdad. $143 \mathrm{pp}$.

14. Mohammed, S. S. (2010). Evaluation the quality of water in Al-Masab Alamm river in Thi-Qar Governorate. M.Sc. Thesis. Univ. of Thi-Qar. $106 \mathrm{pp}$.

15. APHA. (1992). Standard Methods For The Examination of Water and Waste Water. American Public Health Association, $18^{\text {th }}$ ed., Academic Press. Washington D.C. pp. 214-218.

16. Chester, R. and Voutsinou, F.G. (1981). The initial assessment of trace metal pollution in coastal sediments. Mar. Pollut. Bull. 12: 84-91.

17. R.O.P.M.E. (1982). Manual of oceanographic observation and pollutant analysis Methods . ROPME /P. O. Box 26388, 13124 Safa, Kuwait.

18. APHA ( American Public Health Association). (1988). Standard Method for the Examination of water and Wastewater, $20^{\text {th }}$ ed., Washington, DC.

19. El-Wakeel, S.K. and Riely, J.P. (1957). The determination of organic carbon in marine mud. J.Cons.Int.Explor.Mer.12:180-189.

20. Shepard, E. (1954). Nomenclature based on sand- silt- clay ratio. J. Mar. Sc., 17:1-8.

21. Folk. R.L. (1974). "Petrology of sedimentary Rocks" Hemphil publication Co Auslin, Texas.

22. Boyd, C.E. (1990). Water Quality in ponds for aquaculture. Agric. Exper. Station, Auburn Univ., Alabama, U.S.A: 482.

23. Kassim, T.I. (1986). An ecological study on benthic algae for some marshlands southern of Iraq. M.Sc. Thesis, Univ. of Basrah. 102 pp.

24. Al-Ghanemi, H.A.H. (2010). Use of Aquatic Plants as Bioindicators of Heavy Metals in Euphrates river- Iraq. M.Sc. Thesis, Univ. of Babylon. 196 pp.

25. Al-Awady, A.A.M. (2012). Distribution and concentration some trace metals in water, sediment and two species of commercial fish from Al-Masab Alamm river near the Al-Nassiriyia city- south of Iraq. Ph.D.Thesis.College of science for women-Baghdad university.192pp.

26. Al-Helaly. S.H. (2010). An investigation of some heavy metals in water, sediment and some biota of Al-Garraf river, south of Iraq; M.Sc. Thesis. University of Baghdad.120pp. 
27. Al-Lammi, A.A., Kassim, T.I. and Al-Dylymei, A.A. (1999). Alimnology study on tigris river, Iraq, scientific journal of Iraq Atomic commission. vol.1:123-135.

28. Al-Khafaji, B.Y, Mohsin, A.M., Al-Awady, A.A. (2012). Concentration of some heavy metals in water and sediment of Al-Chibaysh Marsh south of Iraq.Conference on Environmental sciences $4^{\text {th }}$ 5-6/December/2012.180-196.

29. Al-Rekabi, H.Y. (1992). Ecological and physiological study on some aquatic plants in Al-Hammar marsh- Iraq., M.Sc. Thesis. Univ. of Basrah, Iraq. 102 pp.

30. Fang, TH., Lin, CL. (2002). 'Dissolved and particulate trace metals and their partitioning in a hypoxic estuary: the Tanshui estuary in northern Taiwan', Estuaries and Coasts. Vol. 25, no. 4, pp. 598-607.

31. EL-Nemaki, FA, Ali, NA, Zeinhom, MM., Radwan, OA. (2008). 'Imacts of different water resources on the ecological parameters and the qulity of tilapia production at El-Abbassa Fish farms in Egypt'.

32. Al-Khafaji, B.Y.; Dawood, Y.T. and Maktoof, A.A. (2012). Trace metals distribution in fish tissues(Cyprinus carpio and Barbus luteus) and sediment from Al-Massab Alamm river near the center of Al-Nassiriyia city.J.Thi-Qar Sci, 3(2):22-30.

33. Kaiser, E., Arscott, D.B., Tockner, K. and Sulzberger, B. (2004). Sources and distribution of organic carbon and nitrogen in the Tagliamento river, Italy. Aquat. Sc. 66:103-116.

34. Dhir, B. and Kumar, R. (2010). Adsorption of heavy metals by Salvinia biomass and agricultural residues. Int. J. Environ. Res. 4 (3): 427-432.

35. Harding, J.P.C. and Whitton, B.A. (1978). Zinc, Cadimum \& Lead in water, sediments \& submerged plants of derwent reservoir, Northern England. Water Research. 12: 307-316.

36. Vardanyan, L., Schider, K., Sayadyan, H., Heege, T., Heblinski, J., Goldberg, E.D., Koide, M. and Hodge, V. (1983). VS Mussel watch:1977-1978 result on trace metals and radio muclides. Estuar. Coast. Mar.Sci. (16):69-93.

37. Bowen, H.J.M. (1966). "Trace elements in biochemistry" Academic Press, Inc., New York. 241 pp.

38. Nolting, R.F. (1986). Copper, Zinc, Cadmium, Nickel, Iron, and Manganese in the southern Bight of the north sea. Mar. Pollut. Bull. 17(3): 113-117.

39. Al-Taee, M.M.S. (2001). Distribution of $\mathrm{Co}, \mathrm{Fe} \& \mathrm{Zn}$ in Shatt Al-Hilla sediments. J. of Babylon University. 6 (3): 565-572.

40. Al-Imarah, F.J.M. (2002). Levels of trace metals in the water of Shatt Al-Arab river Marina Mesopotamia . 16 (1): 257-265.

41. Salman, J.M. (2006). Environmental study of possible pollutants in Euphrates river from AlHindiya Barrage to Al-Kufa -Iraq. Ph.D. Thesis, College of Science. Univ. of Babylon. $197 \mathrm{pp}$.

42. Al-Khafaji, B.Y. (2010). Distribution Pattern of Selected Heavy metals in Water, Sediments and two species of fish from Al-Hammar Marsh south of Iraq. The $5^{\text {th }}$ Scientific Conference 2011college of Science- Babylon Univ., 5: 115-124.

43. Bryan, G.W. (1976). Metal concentration in the sea. Mar. Poll. Bull. 7: 353-356.

44. Grabowski, L.A., Houpis, AJ.L., Woods, W.I. and Johnson, K.A. (2001). Seasonal bioavailability of sediment associated heavy metals a long the Mississippi river floodplain Chemosphere. Vol45,4-5, 51-643.

45. Bentivegna, C.S., Alfano, J.E., Bugel, S.M. and Czechowicz, K. (2004). "Influence of sediment characteristics on heavy metal toxicity in an Urban Marsh. Urban Habitats. 2 (1): 91-111.

46. Binning, K. and Baird, D. (2001). Survey of heavy metals in the sediments of Swartkops river estuary, Port Elizabeth South Africa. Water SA. 27 (4): 461-466.

47. Al-Haidary, M.J.S. (2009). Diurnal variations heavy metal concentration in Al-Kufa river Najaf / $10^{\text {th }}$ international conference on the Chihuahua, Chih. Mexico, July, 2009.

48. Mashkhool, M.A. (2012). Concentration of some heavy metals in water, sediments and types of plants in Al-Cibayish marsh in Thi-Qar province in southern Iraq. MSc thesis University of Queensland.79pp. 